\title{
ION EXCHANGE PROCESS FOR SEPARATING AMERICIUM AND CURIUM FROM IRRADIATED PLUTONIUM
}

\author{
J. A. KELLEY
}

THIS DOCUMENT CONFIRMED AS

DIVISION OF CLASIFIED

(
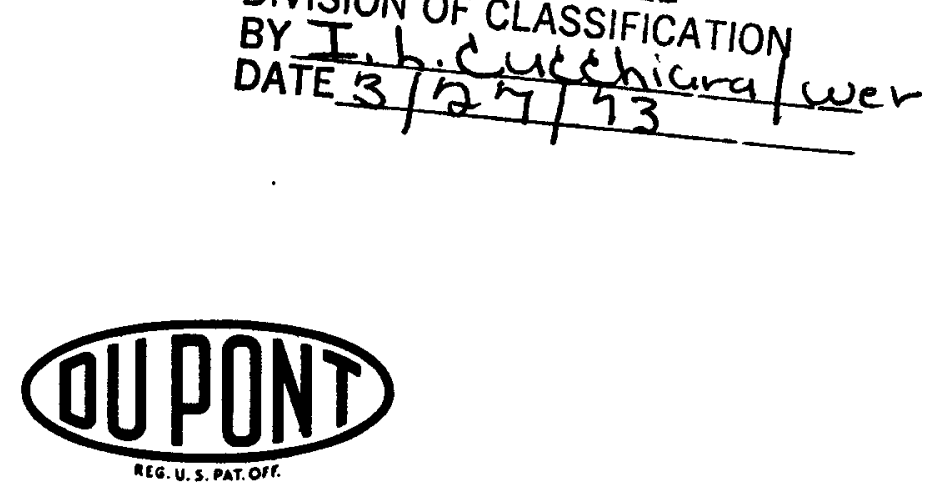

Savannah River Laboratory

Aiken, South Carolina

R930? 


\section{NOTICE}

This report was prepared as an account of work sponsored by the United States Government. Neither the United States nor the United States Atomic Energy Commission, nor any of their employees, nor any of their contractors, subcontractors, or their employees, makes any warranty,

- express or implied, or assumes any legal liability or responsibility for the accuracy, completeness or usefulness of any information, apparatus, product or process disclosed, or represents that its use would not infringe privately owned rights.

Printed in the United States of America

Available from

National Technical Information Service

U. S. Department of Commerce

5285 Port Royal Road

Springfield, Virginia 22151

Price: Printed Copy $\$ 3.00$; Microfiche $\$ 0.95$ 


\section{DISCLAIMER}

This report was prepared as an account of work sponsored by an agency of the United States Government. Neither the United States Government nor any agency Thereof, nor any of their employees, makes any warranty, express or implied, or assumes any legal liability or responsibility for the accuracy, completeness, or usefulness of any information, apparatus, product, or process disclosed, or represents that its use would not infringe privately owned rights. Reference herein to any specific commercial product, process, or service by trade name, trademark, manufacturer, or otherwise does not necessarily constitute or imply its endorsement, recommendation, or favoring by the United States Government or any agency thereof. The views and opinions of authors expressed herein do not necessarily state or reflect those of the United States Government or any agency thereof. 


\section{DISCLAIMER}

Portions of this document may be illegible in electronic image products. Images are produced from the best available original document. 
DP-1308

Chemistry

(TID-4500, UC-10)

\title{
ION EXCHANGE PROCESS FOR SEPARATING AMERICIUM AND CURIUM FROM IRRADIATED PLUTONIUM
}

\author{
by \\ J. A. Kelley
}

Approved by

J. A. Porter, Research Manager Separations Chemistry Division

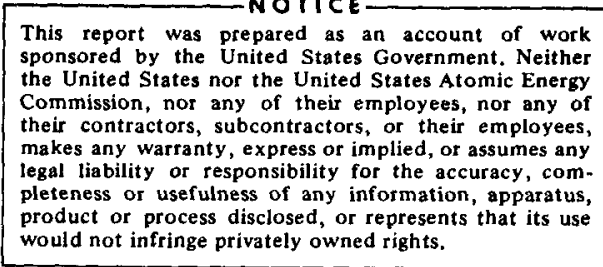

would not infringe privately owned rights.

November 1972

E. I. DU PONT DE NEMOURS \& COMPANY

SAVANNAH RIVER LABORATORY

AIKEN, S. C. 29801

CONTRACT AT(07-2)-1 WITH THE

UNITED STATES ATOMIC ENERGY COMMISSION 


\section{ABSTRACT}

An ion exchange process was developed for separating americium and curium from each other and from fission products in a lanthanide (Ln) - actinide (An) concentrate containing a high $\mathrm{Ln} / \mathrm{An}$ ratio and a significant amount of ${ }^{242} \mathrm{Cm}$. The In-An mixture was produced by irradiating ${ }^{239} \mathrm{Pu}$ in the program to prepare higher actinide precursors of ${ }^{232} \mathrm{Cf}$. 


\section{CONTENTS}

\section{Page}

Introduction ................... 6

Summary . . . . . . . . . . . . . . . 8

Description of Plutonium Burner Concentrate . . . . . 9

Lanthanide-Actinide Loading Curve . . . . . . . . 10

Nonradioactive Tests . . . . . . . . . . 10

Tracer Test . . . . . . . . . . . . . 12

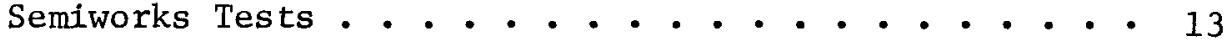

Displacement Development Chromatography . . . . . . 14

Band Length Requirements . . . . . . . . . . 14

Nonradioactive Scouting Tests . . . . . . . . 15

Curium-Americium Test . . . . . . . . . . . 19

Semiworks Tests................. 20

Remova1 of Residual Fission Products from Resin . . . 22

Proposed Process . . . . . . . . . . . . . 24

Acknowledgment . . . . . . . . . . . . . . 25

Appendices

A. Equilibrium Treatment for Colum Loading . . . 26

B. Band Length Requirements for Curium-Americium

Separation ........... 30

References ................. . . 39 


\section{LIST OF TABLES}

$\underline{\text { Table }}$

Page

I Actinides and Fission Products in Solvent Extraction Concentrate (About 1 year cooling) . . 9

II Decay Heats of Actinides and Fission Products in Solvent Extraction Concentrate (About 1 year cooling) . . . . . . . . . . 10

III Sorption of $\mathrm{Pr}^{3+}, \mathrm{H}^{+}$, and $\mathrm{Na}^{+}$from Nitrate Solutions by "Dowex" $50 \mathrm{~W}-\mathrm{X} 8$ Resin at $70^{\circ} \mathrm{C}$. . . 11

IV Band Length Requirements for Plutonium Burner Concentrate with DTPA as Elutriant . . . . . 15 


\section{LIST OF FIGURES}

Figure

Page

1 Fit of Sorption Data Assuming Constant

Ratios of Activity Coefficients in Resin and

Aqueous Phases................

2 Theoretical Plate Height as a Function of $\mathrm{pH}$ at 16 and $32 \mathrm{ml} /\left(\mathrm{min}-\mathrm{cm}^{2}\right)$. . . . . . 16

3 Variation of Neodymium Peak Concentration with $\mathrm{pH}$ of DTPA . . . . . . . . . . 17

4 Separation of Samarium, Neodymium, and Praseodymium with $0.05 \mathrm{M}$ DTPA at $\mathrm{pH} 3.0$ and $50 \mathrm{ml} /\left(\mathrm{min}-\mathrm{cm}^{2}\right)$. . . . . . . 18

5 Separation of ${ }^{244} \mathrm{Cm}$ and ${ }^{243} \mathrm{Am}$ with $0.05 \mathrm{M}$ DTPA at $\mathrm{pH} 3.0$ as Elutriant . . . . . . 19

6 Semiworks Test of Ion Exchange Process with 8-, 6-, 4-, and 2-inch Colums ......... 21

i Removal of Nendymium from a 1/3-Loaded

Column with DTPA . . . . . . . . . . 23 


\section{INTRODUCTION}

${ }^{239} \mathrm{Pu}$ is irradiated, or burned, in a Savannah River nuclear reactor in the program to produce higher actinide precursors of $252 \mathrm{Cf}$. After cooling, the targets are dissolved and processed by solvent extraction to isolate residual plutonium and a transplutonium fraction also containing lanthanide fission products. The americium and curium in the transplutonium fraction are separated and purified by ion exchange in the Multipurpose Processing Facility (MPPF), a series of manipulator-operated cells in the 221-F canyon building.

Ion exchange process development was required because of the large quantities of lanthanides, entrained sodium, and ${ }^{242} \mathrm{Cm}$.

Pressurized cation exchange chromatography was used at the Savannah River Laboratory to separate $100 \mathrm{~g}$ batches of ${ }^{244} \mathrm{Cm}$ and ${ }^{243} \mathrm{Am}$ in a curium production campaign $(\mathrm{Cm}-\mathrm{II}) .{ }^{1},{ }^{2} \mathrm{Cm}-\mathrm{II}$ ion exchange feed had a Ln/An ratio of $25: 1$ and contained no ${ }^{242} \mathrm{Cm}$. ${ }^{252} \mathrm{Cf}$, produced at the Savannah River Plant by irradiating ${ }^{242} \mathrm{Pu}$ in a californium campaign ( $\mathrm{Cf}-\mathrm{I})$, can also be separated by pressurized cation exchange chromatography with the Cm-II process. Cf-I material has a Ln/An ratio of $22: 1$ and contains no ${ }^{242} \mathrm{~cm}$. By contrast plutonium burner concentrate has a Ln/An ratio of 17:1. The high $\mathrm{Ln} / \mathrm{An}$ ratio lowers the quantity of americium and curium that can be processed per ion exchange batch. A batch of plutonium burner targets processed through solvent extraction contained 177 moles of lanthanides and actinides. If this material were processed in MPPF at the maximum rate specified by $\mathrm{Cf}-\mathrm{I}$ process, 2.4 moles/batch, 74 ion exchange batches would be required to complete the campaign.

The solvent extraction concentrate also contained a large amount of entrained $\mathrm{NaNO}_{3}$, expected to be $\sim 300$ moles after recycle through solvent extraction. Before this work, no suitable method was available for determining the number of moles of LntAn that could be sorbed on an ion exchange bed from solutions containing monovalent cations at various concentrations.

After about one year cooling, the solvent extraction concentrate contained $\sim 20 \mathrm{~g}$ of ${ }^{242} \mathrm{Cm}$ and $\sim 700 \mathrm{~g}$ of ${ }^{244} \mathrm{Cm}$, which produce $\sim 4400$ watts from alpha decay. The Cm-II or Cf-I process could not be used for purifying the concentrate because the small size ion exchange columns would overheat during elution. 
This report describes a method for determining the efficiency of Ln-An sorption from solutions containing monovalent cations, a process for purification of $242,244 \mathrm{Cm}$ and americium from large quantities of lanthanides, and a method for removing residual fission products from an ion exchange column. 


\section{SUMMARY}

A process was developed for separating americium and curium from each other and fission products in the Ln-An concentrate from plutonium burner targets. A method for determining the number of moles of Ln+An that can be loaded on an ion exchange bed from solutions containing various concentrations of $\mathrm{NaNO}_{3}$, $\mathrm{HNO}_{3}$, and $\mathrm{Ln}-\mathrm{An}\left(\mathrm{NO}_{3}\right)_{3}$ was developed. A chromatographic ion exchange process was developed for separating curium and americium with $0.05 \mathrm{M}$ diethylenetriaminepentaacetic acid (DTPA), at $\mathrm{pH} 3.0$ and a flow of $32 \mathrm{ml} /\left(\mathrm{min}-\mathrm{cm}^{2}\right)$; this high flow minimizes column heatup and resin degradation. The most efficient agent for removing residual fission products from ion exchange resin was $0.3 \mathrm{M}$ DTPA at $\mathrm{pH} 8.0$. 


\section{DESCRIPTION OF PLUTONIUM BURNER CONCENTRATE}

The plutonium burner concentrate is primarily a mixture of curium, americium, and lanthanide fission products obtained after plutonium is removed by solvent extraction. Table I shows the quantities of actinides and lanthanides in a batch of solvent extraction concentrate after about 1 year cooling. After recycle through solvent extraction, the concentrate will also contain $\sim 300$ moles of entrained $\mathrm{NaNO}_{3}$ and 13 moles of $\mathrm{PO}_{4}{ }^{3-}$ from degraded TBP. A feed batch is adjusted to $\sim_{1 M} \mathrm{HNO}_{3}$ by formic acid denitration before the ion exchange column is loaded. At lower acidity, Ln-An phosphates could precipitate.

\begin{tabular}{|c|c|c|c|c|}
\hline \multirow[b]{2}{*}{ Actinide } & \multicolumn{4}{|c|}{$\begin{array}{c}\text { Actinides and Fission Products in } \\
\text { Solvent Extraction Concentrate } \\
\text { (About l year cooling) }\end{array}$} \\
\hline & $\mathrm{kg}$ & Moles & Lan thanide & Moles \\
\hline${ }^{241} \mathrm{Am}$ & 0.05 & 0.21 & $\begin{array}{l}\mathrm{La} \\
\mathrm{Ce}\end{array}$ & $\begin{array}{l}20.5 \\
41.6\end{array}$ \\
\hline $242 \mathrm{~m}_{\mathrm{Am}}$ & 0.001 & - & $\begin{array}{l}\mathrm{Pr} \\
\mathrm{Nd}\end{array}$ & $\begin{array}{l}19.1 \\
59.9\end{array}$ \\
\hline${ }^{243} \mathrm{Am}$ & 1.7 & 7.00 & $\begin{array}{l}\mathrm{Pm} \\
\mathrm{Sm}\end{array}$ & $\begin{array}{c}0.78 \\
16.6\end{array}$ \\
\hline${ }^{242} \mathrm{Cm}$ & 0.02 & 0.08 & $\begin{array}{l}\mathrm{Eu} \\
\mathrm{Gd}\end{array}$ & $\begin{array}{l}2.87 \\
5.72\end{array}$ \\
\hline${ }^{244} \mathrm{Cm}$ & 0.7 & 2.87 & $\begin{array}{l}\mathrm{Tb} \\
\mathrm{Dy}\end{array}$ & $\begin{array}{l}0.03 \\
0.01\end{array}$ \\
\hline${ }^{245} \mathrm{Cm}$ & 0.004 & $\frac{0.02}{10.2}$ & & $\frac{-}{167}$ \\
\hline
\end{tabular}

Total An+Ln $=177$ moles

After about 1 year cooling, the concentrate produces $\sim 4400$ watts from alpha decay of ${ }^{242} \mathrm{Cm}$ and ${ }^{244} \mathrm{Cm}$ and 212 kilowatts from beta-gamma decay of fission products. Table II shows decay heats from actinides and fission products in the solvent extraction concentrate. 
TABLE II

Decay Heats of Actinides and Fission Products in Solvent Extraction Concentrate

(About l year cooling)

\begin{tabular}{|c|c|c|c|c|}
\hline Actinide & $\begin{array}{l}\alpha \text { Heat, } \\
\text { watts }\end{array}$ & $\begin{array}{l}\text { Fission } \\
\text { Product }\end{array}$ & $\begin{array}{c}\beta \text { Heat, } \\
\text { watts }\end{array}$ & $\begin{array}{c}\gamma \text { Heat, } \\
\text { watts }\end{array}$ \\
\hline${ }^{241} \mathrm{Am}$ & 5 & ${ }^{91} \mathrm{Y}$ & 31 & 0 \\
\hline${ }^{243} \mathrm{Am}$ & 10 & $95 \mathrm{Zr}$ & 3 & 19 \\
\hline $242 \mathrm{Cm}$ & 2400 & $95 \mathrm{Nb}$ & 3 & 37 \\
\hline \multirow[t]{8}{*}{$244 \mathrm{Cm}$} & 2000 & $103 \mathrm{Ru}$ & 0 & 3 \\
\hline & & $106 \mathrm{Ru}$ & 27 & 0 \\
\hline & & ${ }^{106} \mathrm{Rh}$ & 2188 & 509 \\
\hline & & ${ }^{141} \mathrm{Ce}$ & 1 & 1 \\
\hline & & $144 \mathrm{Ce}$ & 654 & $32 \overline{1}$ \\
\hline & & $1{ }^{44} \mathrm{Pr}$ & 7296 & 603 \\
\hline & & $147 \mathrm{Pm}$ & 51 & 0 \\
\hline & & $154 \mathrm{Eu}$ & 20 & 120 \\
\hline Total $\rightarrow$ & 4400 & & 10,270 & 1610 \\
\hline
\end{tabular}

Total heat from $\alpha+\beta+\gamma=16,300$ watts

\section{LANTHANIDE-ACTINIDE LOADING CURVE}

Tests were made to develop a method for determining the number of moles of In+An that can be loaded on an ion exchange column from solutions of various $\mathrm{HNO}_{3}, \mathrm{NaNO}_{3}$, and $\mathrm{Ln}-\mathrm{An}\left(\mathrm{NO}_{3}\right)_{3}$ concentrations. Some distribution data for sorption of cations from $\mathrm{HNO}_{3}$ are available, ${ }^{3}$ but these data do not cover the concentration ranges of interest. A method applicable to plutonium burners was developed in small-scale nonradioactive tests, an intermediate scale tracer-level test, and full-scale semiworks tests. A general equilibrium treatment for sorption of an nvalent cation from a mixture of two monovalent cations, and specific equations for $\mathrm{Pr}^{3+}, \mathrm{Na}^{+}$, and $\mathrm{H}^{+}$are given in Appendix A.

\section{NONRADIOACTIVE TESTS}

To develop a loading curve, sorption tests were made with standardized $\operatorname{Pr}\left(\mathrm{NO}_{3}\right)_{3}$ solution to simulate the behavior of all lanthanides and actinides. $\operatorname{Pr}^{3+}$ was sorbed onto "Dowex"* 50W-X8,

* Registered trademark of Dow Chemical Co. 
200-400 mesh resin in a 2.0-cm-diameter by $76-\mathrm{cm}-$ long steel column, which was maintained at $70^{\circ} \mathrm{C}$. The capacity of the resin bed was determined by passing excess $0.1 \mathrm{M} \operatorname{Pr}\left(\mathrm{NO}_{3}\right)_{3}$ through the column, rinsing the column with deionized water, stripping sorbed $\mathrm{Pr}^{3+}$ with $2 \mathrm{M} \mathrm{HNO}_{3}$, and determining the amount of sorbed $\mathrm{Pr}^{3+}$ by EDTA titration. Before each test, resin was converted to the $\mathrm{Zn}^{2+}$ form by passing excess $0.5 \mathrm{M} \mathrm{Zn}\left(\mathrm{NO}_{3}\right)_{2}$ through the column. A solution containing known concentrations of $\operatorname{Pr}\left(\mathrm{NO}_{3}\right)_{3}, \mathrm{NaNO}_{3}$, and $\mathrm{HNO}_{3}$ was passed through the column at $8 \mathrm{ml} /\left(\mathrm{min}-\mathrm{cm}^{2}\right)$, and the column was rinsed with deionized water. The amount of nonsorbed $\mathrm{Pr}^{3+}$ was determined spectrophotometrically. Before the next test, $\mathrm{Pr}^{3+}$ was stripped from the column with $2 \mathrm{M} \mathrm{HNO}_{3}$. Results of these tests are shown in Table III. Several of the tests were repeated at a flow of $4 \mathrm{ml} /\left(\mathrm{min}-\mathrm{cm}^{2}\right)$, but no significant differences were observed.

\section{TABLE II I}

Sorption of $\mathrm{Pr}^{3+}, \mathrm{H}^{+}$, and $\mathrm{Na}^{+}$from Nitrate Solutions by "Dowex" $50 \mathrm{~W}-\mathrm{x} 8$ Resin at $70^{\circ} \mathrm{C}$

\begin{tabular}{|c|c|c|c|}
\hline$\left[\operatorname{Pr}\left(\mathrm{NO}_{3}\right)_{3}\right], \mathrm{M}$ & {$\left[\mathrm{HNO}_{3}\right], \mathrm{M}$} & {$\left[\mathrm{NaNO}_{3}\right], \mathrm{M}$} & $\begin{array}{c}\text { Fraction of Resin } \\
\text { in } \mathrm{Pr}^{3+} \text { Form, } f \\
\end{array}$ \\
\hline 0.02 & 1.0 & 2.1 & 0.192 \\
\hline 0.02 & 1.0 & 2.5 & 0.169 \\
\hline 0.03 & 1.5 & 4.0 & 0.102 \\
\hline 0.04 & 1.0 & 5.0 & 0.112 \\
\hline 0.05 & 0.6 & 4.5 & 0.165 \\
\hline 0.06 & 1.0 & 5.0 & 0.147 \\
\hline 0.07 & 1.5 & 4.2 & 0.175 \\
\hline 0.09 & 1.1 & 4.1 & 0.242 \\
\hline 0.10 & 1.5 & 2.7 & 0.300 \\
\hline 0.10 & 1.5 & 3.0 & 0.269 \\
\hline 0.10 & 1.1 & 3.0 & 0.306 \\
\hline 0.11 & 1.2 & 3.6 & 0.283 \\
\hline 0.20 & 1.5 & 3.0 & 0.395 \\
\hline 0.20 & 0.7 & 2.5 & 0.561 \\
\hline 0.30 & 1.5 & 3.0 & 0.485 \\
\hline 0.30 & 0.5 & 0.8 & 0.836 \\
\hline 0.40 & 0.5 & 0.16 & 0.956 \\
\hline 0.40 & 1.4 & 2.5 & 0.568 \\
\hline 0.50 & 1.4 & 2.5 & 0.615 \\
\hline 0.50 & 1.5 & 2.0 & 0.648 \\
\hline 0.60 & 1.5 & 2.0 & 0.684 \\
\hline 0.60 & 1.0 & 0.3 & 0.885 \\
\hline 0.80 & 1.5 & 2.5 & 0.690 \\
\hline 1.0 & 0.25 & 0.16 & 0.983 \\
\hline 1.0 & 0.50 & 0.5 & 0.963 \\
\hline
\end{tabular}


Figure 1 shows a plot of $f$ versus $\sigma$, where $f$ is the fraction of resin in the $\mathrm{Pr}^{3+}$ form and

$$
\sigma=\frac{0.125\left[\mathrm{Na}^{+}\right]+0.057\left[\mathrm{H}^{+}\right]}{\left[\mathrm{Pr}^{3+}\right]^{1 / 3}}
$$

The solid line in Figure 1 represents a theoretical curve derived from the equilibrium treatment (Appendix A), and the open circles are the data in Table III. Ratios of the activity coefficients in both phases (resin and aqueous) were treated as constants. Coefficients in the expression for $\sigma$ were obtained by a least squares analysis of the data in Table III. Treatment of the sorption data with calculated activity coefficients ${ }^{4}$ gave only a slightly better fit to the theoretical curve than the treatment using molar concentrations.

Figure 1 can be used to determine the number of moles of Ln+An that can be loaded on an ion exchange column from solutions of various $\mathrm{Na}^{+}, \mathrm{H}^{+}$, and $\mathrm{Ln}^{3+}-\mathrm{An}^{3+}$ concentrations. This method requires a feed analysis to determine the $\mathrm{Na}^{+}, \mathrm{H}^{+}$, and $\mathrm{Ln}-\mathrm{An}$ concentrations. Other monovalent cationic impurities can be treated as $\mathrm{Na}^{+}$. This method cannot be used to predict loading from solutions containing more than 0.15 equivalent/liter of divalent plus trivalent cations (excluding $\mathrm{Ln}^{3+}$ and $\mathrm{An}^{3+}$ ). These cationic impurities are sorbed by the ion exchange resin and cause breakthrough of lanthanides and actinides.

\section{TRACER TEST}

An intermediate-scale test was made with tracer-level feed to determine whether Figure 1 could be used to predict loading of a larger column than that used in the initial tests. The test was made with a 4-inch-diameter by 4-ft-long steel column and on-line analysis system. Feed was sorbed on "Dowex" 50W-X8, 200-400 mesh, $\mathrm{Zn}^{2+}$-form resin at $75^{\circ} \mathrm{C}$. Column capacity was determined by titrating the acid displaced during resin conditioning with $0.5 \mathrm{M} \mathrm{Zn}\left(\mathrm{NO}_{3}\right)_{2}$. The feed $\left(4.3\right.$ moles $\mathrm{Ce}\left(\mathrm{NO}_{3}\right)_{3}, 8.6$ moles $\mathrm{NaNO}_{3}$, and $\sim 10^{8} \mathrm{dpm} / \mathrm{ml}{ }^{154} \mathrm{Eu}$ ) was loaded from a $5.3-\ell$ feed tank at $8 \mathrm{ml} /\left(\mathrm{min}-\mathrm{cm}^{2}\right)$. Cerium in the feed corresponded to $70 \%$ of the measured column capacity; maximum loading capacity for $\mathrm{Ln}-\mathrm{An}^{3+}$ determined from Figure 1 is $73 \%$. Analysis of the column effluent for ${ }^{154} \mathrm{Eu}$ indicated a breakthrough of $20.03 \%$, indicating that Figure 1 could be used to determine loading for larger columns. 


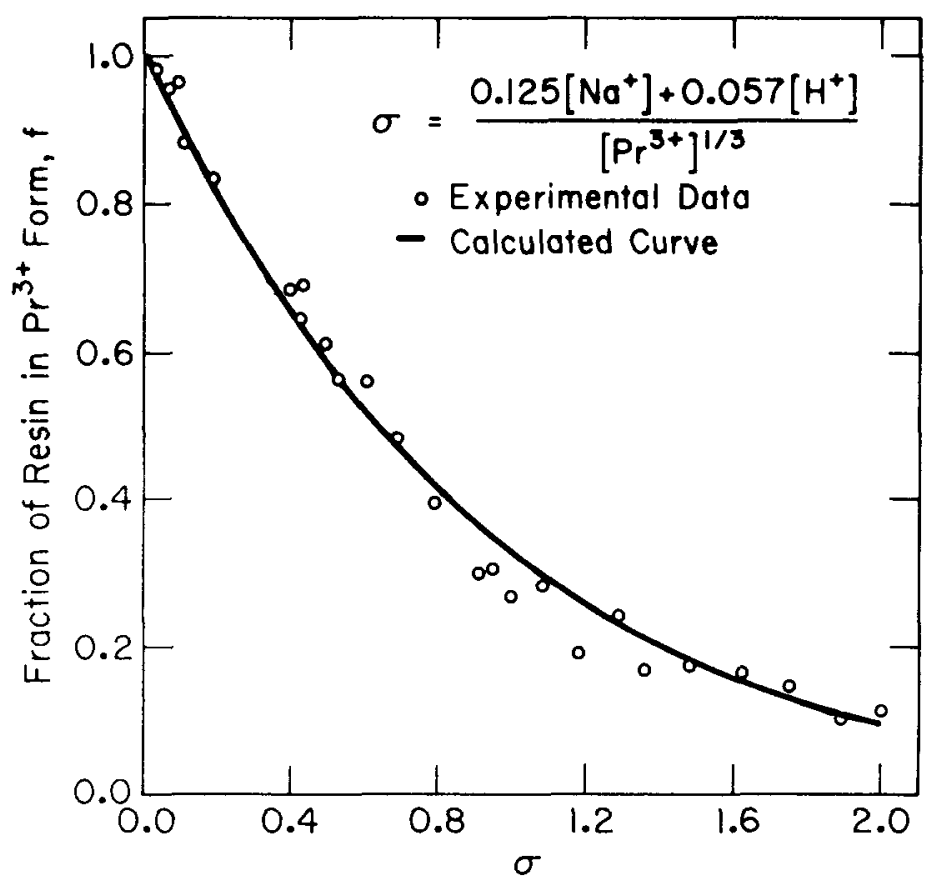

FIGURE 1. Fit of Sorption Data Assuming Constant Ratios of Activity Coefficients in Resin and Aqueous Phases

\section{SEVIIWORKS TESTS}

Tests were made with an 8-inch-diameter by 5-ft-long column to determine loading characteristics of a production-scale column. Test conditions were the same as those in the tracer test. In one test, 18 moles of non radioactive rare earths were successfully loaded from $18 \ell$ of $1 \mathrm{M} \mathrm{HNO}_{3}-2 \mathrm{M} \mathrm{NaNO}_{3}$, approximating a production batch in size and composition. Figure 1 was used to determine that this quantity of feed could be loaded without breakthrough. As a result of these tests, Figure 1 will be used in MPPF to predict the quantity of Ln+An that can be loaded on cation exchange columns. 


\section{DISPLACEMENT DEVELOPMENT CHROMATOGRAPHY}

Small-scale nonradioactive tests, a curium-americium test, and full-scale nonradioactive tests indicated that plutonium burner concentrate could be processed in MPPF at the rate of 18 moles LntAn per ion exchange batch.

After lanthanides and actinides are sorbed onto ion exchange resin, the mixture is separated with a suitable complexing agent, such as DTPA. In the Cm-II campaign, a 4-inch-diameter by 4-ftlong steel column was loaded to $\sim 1 / 3$ capacity with $\sim 2$ moles of LntAn. ${ }^{244} \mathrm{Cm}$ and ${ }^{243} \mathrm{Am}$ were purified with $0.05 \mathrm{M}$ DTPA flowing through the 4-, 3-, 2-, and 1-inch columns at $16 \mathrm{ml} /\left(\mathrm{min}-\mathrm{cm}^{2}\right) .{ }^{2}, 2$ A similar flowsheet is planned for ${ }^{252} \mathrm{Cf}$ separation in MPPF (Cf-I campaign).

With the Cf-I process, 74 ion exchange batches would be required to process plutonium burner concentrate. A larger loading column could be used, but the quantity of ${ }^{242} \mathrm{Cm}$ in each batch would overheat the 2- and 1-inch columns. However, when DTPA at $\mathrm{pH} 6$ is the elutriant, both the 2-inch and 1-inch columns cannot be eliminated from the process. With a 3-inch collection column, the Cm-Am binary fraction would contain all of the curium; no pure curium would be obtained. The objective of this work was to design a plutonium burner process that would have 8- to 10fold greater throughput than the Cf-I process, yet would permit separation of curium and americium and prevent overheating.

\section{BAND LENGTH REQUIREMENTS}

The first step in designing a displacement development ion exchange process is to determine the band lengths of unloaded resin required to separate the elements of interest. A band length can be defined as the number of liters of resin required to sorb the feed; band length can be determined with a feed analysis and Figure 1. Helfferich and James $^{5}$ described a method for calculating the band lengths required to separate a multicomponent mixture by displacement development chromatography. Data required for this calculation are separation factors of the components relative to the last element eluting from the column and mole fraction composition of the mixture to be separated. A more detailed discussion of this method and a computer code to perform the calculations are given in Appendix B. A 1ist of band length requirements for resolution of the solvent extraction 
concentrate is shown in Table IV. Curium is separated from lanthanides after $<0.2$ band length of resolution distance; separation of curium and americium requires 20.5 band length. To account for uncertainties in separation factors and to ensure that equilibrium is reached under actual process conditions, approximately twice the calculated band length requirement is allowed for resolution of curium and americium.

\section{TABLE IV}

band Length Requirements for the Plutonium Burner Concentrate with DTPA as Elutriant

\begin{tabular}{ccc} 
Element & Mole Fraction & $\begin{array}{c}\text { Band Length Required to } \\
\text { Separate from Curium }\end{array}$ \\
\cline { 1 - 1 } $\mathrm{La}$ & 0.114 & 0.126 \\
$\mathrm{Ce}$ & 0.250 & 0.127 \\
$\mathrm{Pr}$ & 0.108 & 0.129 \\
$\mathrm{Nd}$ & 0.323 & 0.134 \\
$\mathrm{Pm}$ & 0.005 & 0.135 \\
$\mathrm{Sm}$ & 0.093 & 0.163 \\
$\mathrm{Ld}$ & 0.016 & 0.179 \\
$\mathrm{\omega u}$ & 0.032 & 0.181 \\
$\mathrm{Am}$ & 0.041 & 0.493 \\
$\mathrm{Cm}$ & 0.018 & -
\end{tabular}

NUNRADIUACTIVE SCOUTING TESTS

the studies of Wheelwright ${ }^{6}$ and Lowe $^{7}$ were extended to determine the effects of flow and $\mathrm{pH}$ of DTPA on the separation of 1. I w . Li. pluseodymium, and samarium were sorbed onto "Dowex" 50W-X8, 200400 mesh, $\mathrm{Zn}^{2+}$-form resin in a 0.5 -inch-diameter by 60-inch-1ong $\mathrm{s} 2 \mathrm{l}$ in lidintained at $70^{\circ} \mathrm{C}$. In each test, the column was lcollor tin 2$] / 3$ capacity. Neodymium, praseodymium, and samarium were used because results of an ion exchange test could be determined quickly and easily by spectrophotometric analysis of the effluent samples. The theoretical plate height (TPH) for each se rarations te" $t$ vas calculated by the method of Wheelwright ${ }^{6}$ anc Low.'

Figure 2 shows results of separation efficiency tests made with $0.05 \mathrm{M}$ DTPA at flows of 16 and $32 \mathrm{ml} /\left(\mathrm{min}-\mathrm{cm}^{2}\right)$ and $\mathrm{pH}$ values of 3 to 6 . The lower $\mathrm{pH} 1$ imit was set at 3 because DTPA crystalizes from a $0.05 \mathrm{M}$ solution at $\mathrm{pH} 2.8$. The TPH for the test with DTPA at $\mathrm{pH} 3$ and $32 \mathrm{ml} /\left(\mathrm{min}-\mathrm{cm}^{2}\right)$ is approximately equal to 


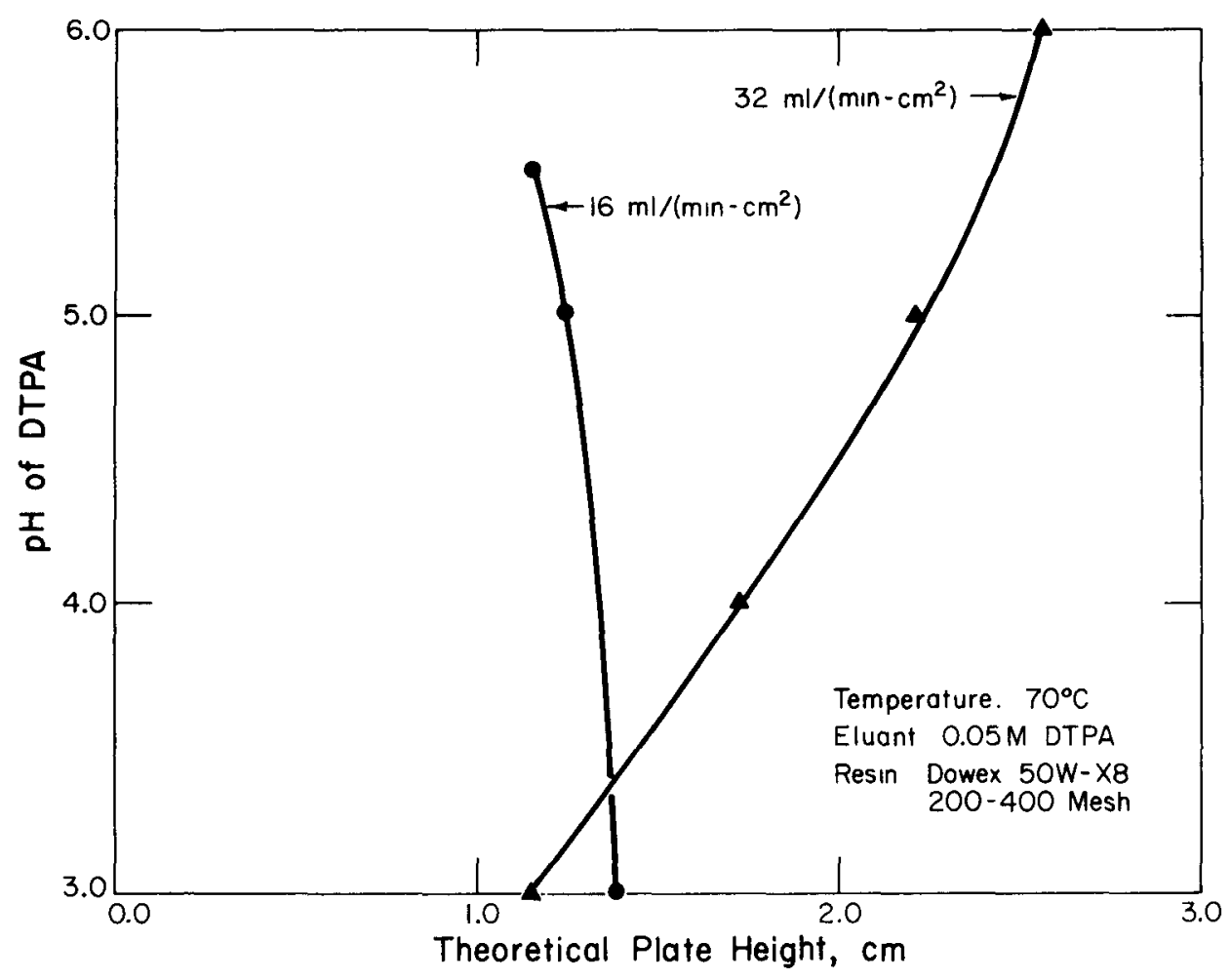

FIGURE 2. Theoretical Plate Height as a Function of $\mathrm{pH}$ at 16 and $32 \mathrm{ml} /\left(\mathrm{min}-\mathrm{cm}^{2}\right)$

that for the test with DTPA at $\mathrm{pH} 6$ and $16 \mathrm{ml} /\left(\mathrm{min}-\mathrm{cm}^{2}\right)$. These tests indicate that excellent separation of curium and americium can be obtained with $0.05 \mathrm{M}$ DTPA at any $\mathrm{pH}$ from 3 to 6 with a flow of $16 \mathrm{ml} /\left(\mathrm{min}-\mathrm{cm}^{2}\right)$. With $0.05 \mathrm{M} \mathrm{DTPA}$ at $32 \mathrm{ml} /\left(\mathrm{min}-\mathrm{cm}^{2}\right)$, $\mathrm{pH} 3$ is required for a low IPH and good separation of curium and americium.

Figure 3 shows the variation of neodymium peak concentration with $\mathrm{pH}$ at a flow of $32 \mathrm{ml} /\left(\mathrm{min}-\mathrm{cm}^{2}\right)$. Although neodymium concentration in the column effluent decreased with decreasing $\mathrm{pH}$, the volume of elutriant required to attain breakthrough remained constant. With DTPA at $\mathrm{pH} 3$, the concentrations of lanthanides in the aqueous and resin phases are $\sim 2.6$ times smaller than with DTPA at pH 6. This band spreading in the resin phase is beneficial because the decay heat of ${ }^{242} \mathrm{Cm}$ and ${ }^{244} \mathrm{Cm}$ will be distributed over a larger volume of resin, minimizing the chance of column overheating. With DTPA at $\mathrm{pH} 3$, the product volume is 22.6 times larger than with DTPA at $\mathrm{pH} 6$, but this presents no problem since ample space is available in MPPF for product collection. 


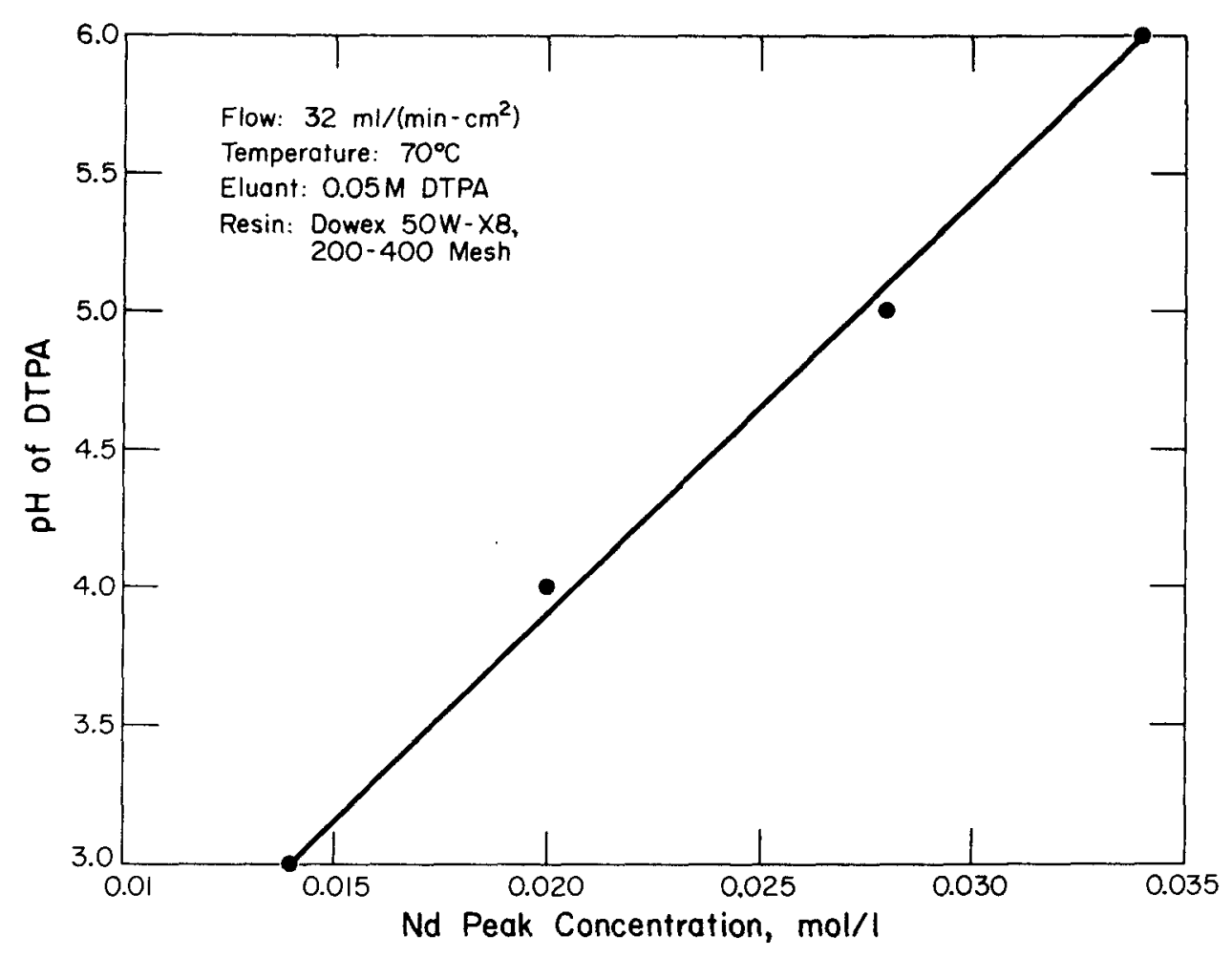

FIGURE 3. Variation of Neodymi um Peak Concentration with $\mathrm{pH}$ of DTPA 
A test was made at $50 \mathrm{ml} /\left(\mathrm{min}-\mathrm{cm}^{2}\right)$ to extend the range of usefulness of $0.05 \mathrm{M}$ DTPA, $\mathrm{pH} 3$, as an elutriant. Figure 4 shows the results of a test made with samarium, neodymium, and praseodymium. The mixture was separated satisfactorily at a flow $>3$ times that used in the Cm-II campaign. Flows in this range will not be needed to process plutonium burner concentrate, but this test demonstrates the versatility of $0.05 \mathrm{M}$ DTPA at $\mathrm{pH} 3.0$ as an elutriant.

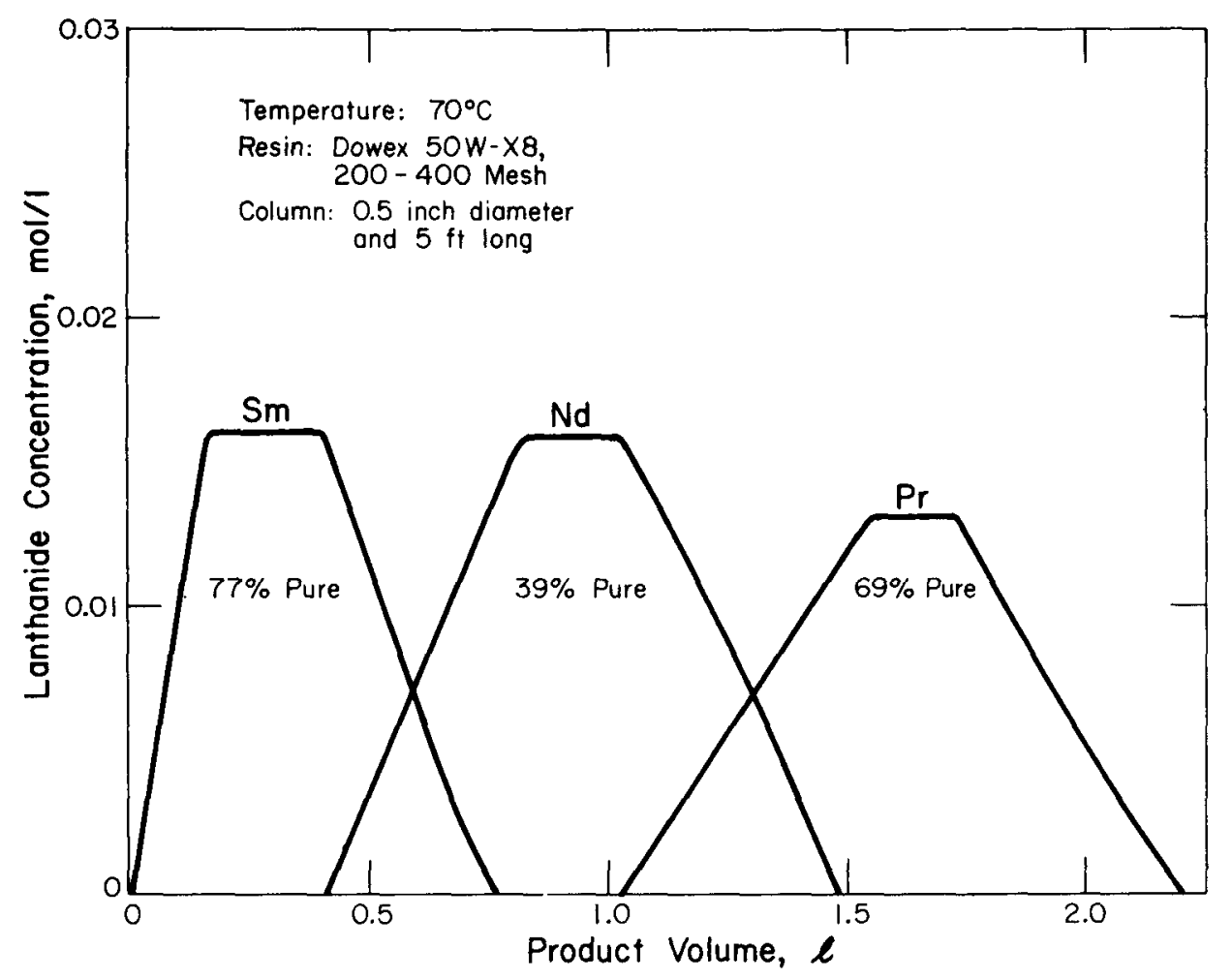

FIGURE 4. Separation of Samarium, Neodymium, and Praseodymium with $0.05 \mathrm{M}$ DTPA at $\mathrm{pH} 3.0$ and $50 \mathrm{ml} /\left(\mathrm{min}-\mathrm{cm}^{2}\right)$ 


\section{CURIUM-AMERICIUM TEST}

A test was made with the Cm-II column system to demonstrate that curium and americium could be separated from simulated plutonium burner concentrate with $0.05 \mathrm{M}$ DTPA at $\mathrm{pH} 3.0$ and $32 \mathrm{ml} /$ $\left(\mathrm{min}-\mathrm{cm}^{2}\right)$. The columns used were 4-, 3-, and 2-inch-diameter by 4-ft-long; filled with "Dowex" 50W-X8, 200-400 mesh, $\mathrm{Zn}^{2+}$-form resin; and maintained at $80^{\circ} \mathrm{C}$. The 4-inch column was loaded to $\sim 80 \%$ capacity with feed containing $81.2 \mathrm{~g}$ of ${ }^{244} \mathrm{Cm}, 75.6 \mathrm{~g}$ of ${ }^{243} \mathrm{Am}, 162 \mathrm{~g}$ of cerium, $60 \mathrm{~g}$ of praseodymium, $250 \mathrm{~g}$ of neodymium, $62 \mathrm{~g}$ of samarium, $9 \mathrm{~g}$ of europium, and $22 \mathrm{~g}$ of gadolinium. Elutriant was pumped at $16 \mathrm{ml} /\left(\mathrm{min}-\mathrm{cm}^{2}\right)$ through the 4- and 3-inch columns, and at $\sim 36 \mathrm{ml} /\left(\mathrm{min}-\mathrm{cm}^{2}\right)$ through the 2-inch column. Figure 5 shows the elution diagram for this test. Approximately $59 \mathrm{~g}$ of pure ${ }^{244} \mathrm{Cm}$ was obtained. Analysis of the data from the $\mathrm{Ge}(\mathrm{Li})$ detector indicated that $\sim 31 \mathrm{~g}$ of pure ${ }^{243} \mathrm{Am}$ was eluted from the 2-inch column.

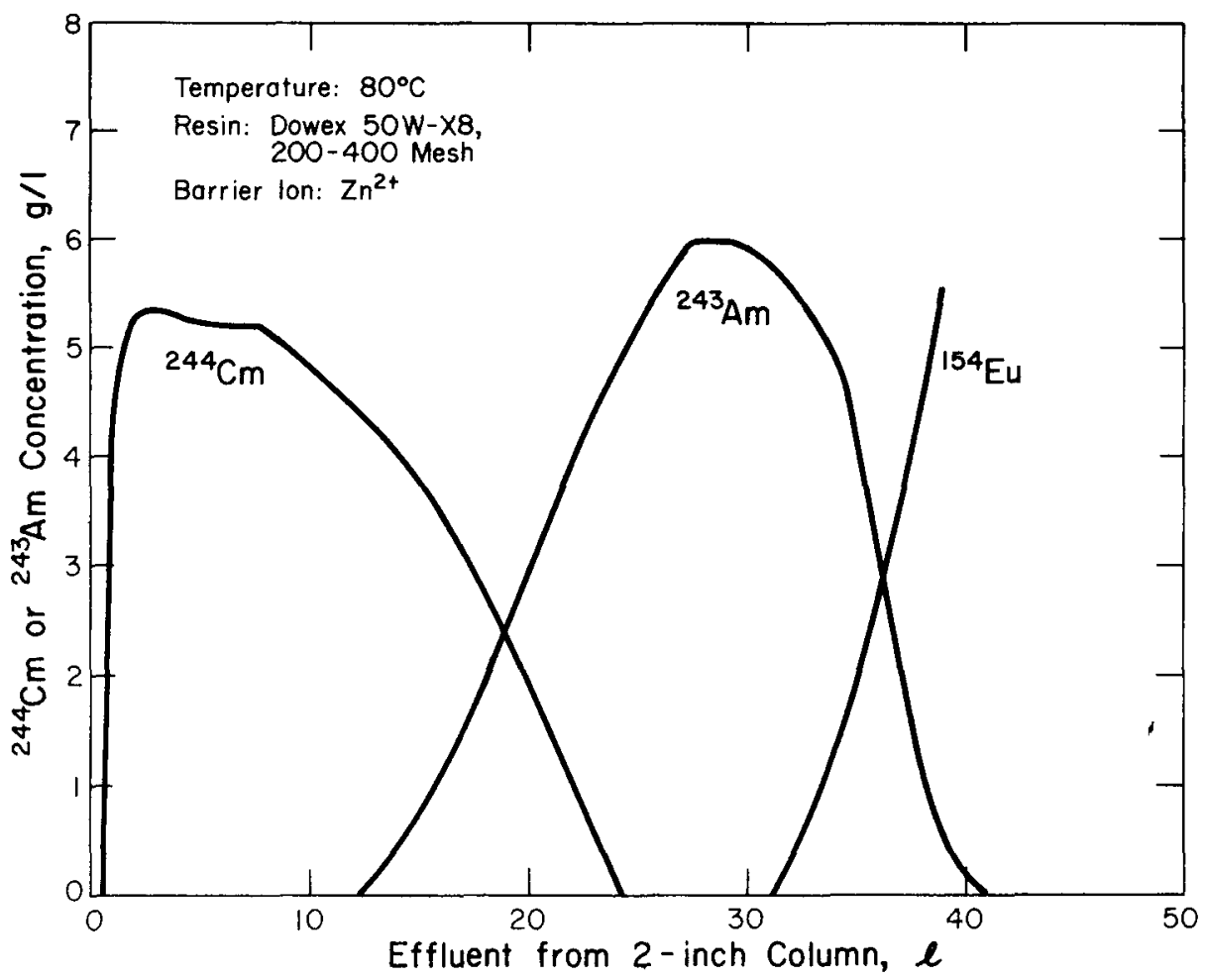

FIGURE 5. Separation of $244 \mathrm{Cm}$ and ${ }^{243} \mathrm{Am}$ with $0.05 \mathrm{M}$ DTPA at $\mathrm{pH} 3.0$ as Elutriant 
This test demonstrated that plutonium burner concentrate can be processed with $0.05 \mathrm{M}$ DTPA at $\mathrm{pH} 3$ as elutriant. With a flow of $\sim 32 \mathrm{ml} /\left(\mathrm{min}-\mathrm{cm}^{2}\right)$ through the 2-inch column, no overheating problems will arise. With DTPA elutriant at $\mathrm{pH} 3$, the quantity of curium in the curium-americium binary on the 2-inch column is lowered from $\sim 60 \mathrm{~g}$ (based upon $\mathrm{Cm}-\mathrm{II}$ experience) to $\sim 25 \mathrm{~g}$.

\section{SEMIWORKS TESTS}

Tests were made to demonstrate the plutonium burner process with a production-size batch of ion exchange feed. The first full-scale tests of the plutonium burner process were made with 10-ft-long columns, 6-, 4-, and 2-inch diameter. Although separation of curium and americium stand-ins (dysprosium and terbium) was excellent, DTPA flows of only 13, 16, and $20 \mathrm{ml} /\left(\mathrm{min}-\mathrm{cm}^{2}\right)$ were obtained through the 6-, 4-, and 2-inch columns, respectively, at the desired pressure limit of $1000 \mathrm{psig}$. A flow of $32 \mathrm{ml} /\left(\mathrm{min}-\mathrm{cm}^{2}\right)$ through the 2-inch column was not obtained even at 2250 psig. Accordingly, another column set was designed with decreased length, increased diameters, and equal volume.

Subsequent semiworks tests were made with these 8-, 6-, 4-, and 2-inch-diameter columns. The 8-inch column was 5-ft-long to provide a resin bed large enough to sorb $\sim 20$ moles of LntAn; the other columns were $4 \mathrm{ft}$ long.

Two tests were made to demonstrate the process with these columns, one at an effluent temperature of $70^{\circ} \mathrm{C}$ and another at $80^{\circ} \mathrm{C}$. All columns were filled with $280 \mu \mathrm{m}$ "Dowex" $50 \mathrm{~W}-\mathrm{X} 8$ resin in the $\mathrm{Zn}^{2+}$-form. Feed for both tests was 18 moles non radioactive lanthanides, 20 moles $\mathrm{HNO}_{3}$, and 40 moles $\mathrm{NaNO}_{3}$. Dysprosium and terbium were used as stand-ins for curium and americium, respectively. The 8 -inch column was loaded at $8 \mathrm{ml} /\left(\mathrm{min}-\mathrm{cm}^{2}\right)$ to $272 \%$ capacity. In the first test, approximately $1.5 \%$ of the feed did not load because feed was loaded from an 18- $l$ volume instead of the desired $20 \ell$. Concentration of the feed resulted in breakthrough as predicted by Figure 1. (In MPPF, the feed will be $\sim 1 \mathrm{M} \mathrm{HNO}_{3}, 2 \mathrm{M} \mathrm{NaNO}$, and $\sim 1 \mathrm{M} \mathrm{Ln}-\mathrm{An}\left(\mathrm{NO}_{3}\right)_{3}$, and will be loaded from an 18- $\ell$ feed tank.) In the second test, $\mathrm{HNO}_{3}$ and $\mathrm{NaNO}_{3}$ were adjusted to $1 \mathrm{M}$ and $2 \mathrm{M}$, respectively, and no breakthrough occurred.

Figure 6 shows the elution diagram for the separation test at $70^{\circ} \mathrm{C}$; the test at $80^{\circ} \mathrm{C}$ gave essentially the same results. Elutriant $(0.05 \mathrm{M}$ DTPA at $\mathrm{pH} 3.0)$ was pumped through the 8-, 6-, and 4-inch columns at $16 \mathrm{ml} /\left(\mathrm{min}-\mathrm{cm}^{2}\right)$ and through the 2-inch column at $32 \mathrm{ml} /\left(\min -\mathrm{cm}^{2}\right)$. The Dy-Tb binary in both tests contained $\sim 20 \mathrm{~g}$ each of dysprosium and terbium, corresponding to 
$30 \mathrm{~g}$ each of curium and americium. Approximately $40 \mathrm{~g}$ of the original $65 \mathrm{~g}$ of dysprosium were lost because of a valving error during elution. Approximately $5 \mathrm{~g}$ of pure dysprosium and the complete Dy-Tb binary were collected from the 2-inch column. Because the size of the Dy-Tb binary eluting from the 2-inch column is not a function of total dysprosium in the column system, the results of this test are valid. The elution diagram shows dysprosium collected from the 2-inch column as a solid line and the remainder, estimated from previous tests, as a dashed line.

These two tests successfully demonstrated the chromatography portion of the plutonium burner process. The solvent extraction concentrate can be processed in MPPF in $\sim 10$ batches. Approximately 18 moles of $\mathrm{L}+\mathrm{An}$ can be loaded on the 8-inch colum from feed solutions containing $21 \mathrm{M} \mathrm{HNO}_{3}$ and $22 \mathrm{M} \mathrm{NaNO}_{3}$. Elution with $0.05 \mathrm{M}$ DTPA at $\mathrm{pH} 3.0$ will give excellent separation of curium and americium. A flow of $32 \mathrm{ml} /\left(\mathrm{min}-\mathrm{cm}^{2}\right)$ through the 2-inch column will prevent overheating from the alpha decay of ${ }^{242} \mathrm{Cm}$ and ${ }^{244} \mathrm{Cm}$.

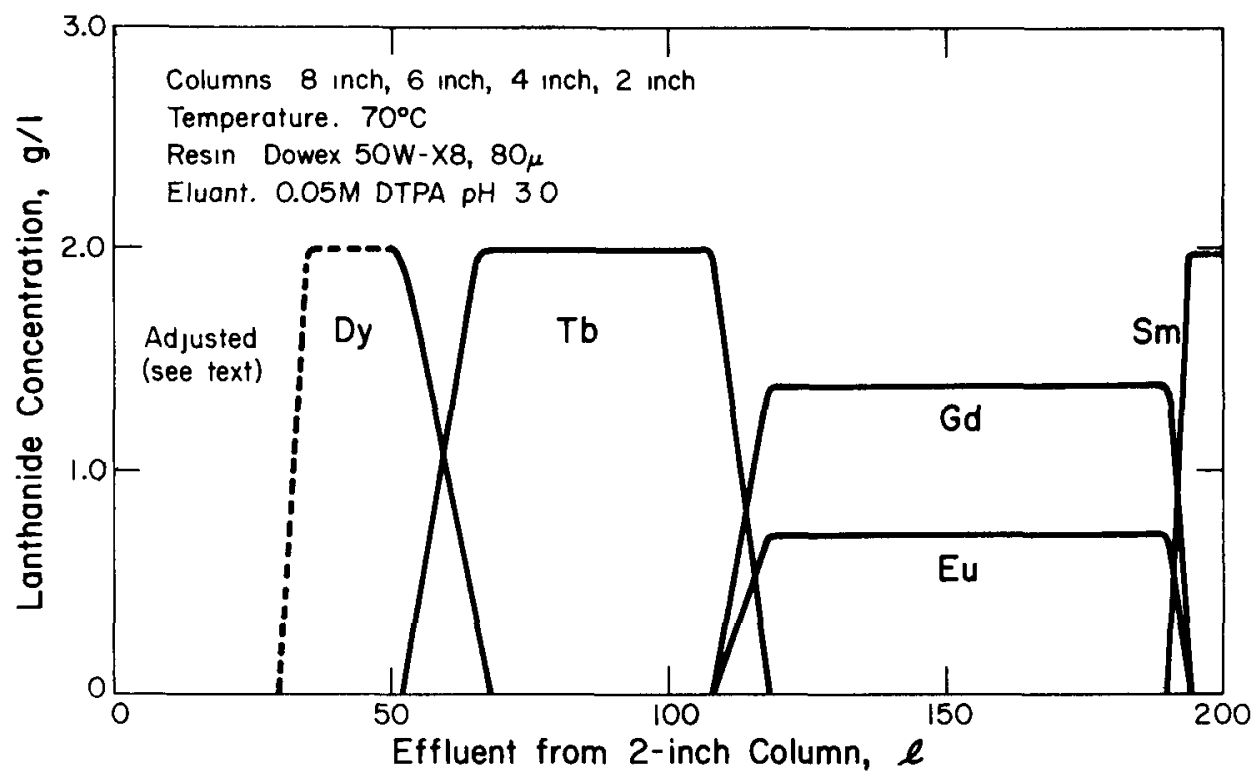

FIGURE 6. Semiworks Test of Ion Exchange Process with 8-, 6-, 4-, and 2-inch Colurins 


\section{REMOVAL OF RESIDUAL FISSION PRODUCTS FROM RESIN}

Tests indicated that $0.3 \mathrm{M}$ DTPA, $\mathrm{pH} 8$, is the most efficient agent for removing residual fission products from ion exchange resin. After curium and americium are collected from the 2-inch column, fission products must be stripped from the resin before the columns are discarded. Because the waste volume generated in the loading and eluting steps is large $(\sim 750 \ell)$, waste generated from column stripping must be minimized.

Figure 7 shows the results of stripping tests made with DTPA at various concentrations and $\mathrm{pH}$ values. In these tests, nonradioactive neodymium was loaded on the top $1 / 3$ of a $0.5-$ inch-diameter by 2.5-ft-long steel column containing "Dowex" 50W-X8 resin, 200-400 mesh. Neodymium was stripped from the resin at $70^{\circ} \mathrm{C}$ and $16 \mathrm{ml} /\left(\min -\mathrm{cm}^{2}\right)$ with the test solution. The most efficient stripping solution from the standpoint of waste volume and DTPA economy was 0.3M DTPA at $\mathrm{pH} 8.0$. Lanthanide removal was slightly faster with $0.5 \mathrm{M}$ DTPA at $\mathrm{pH} 8.0$, but not enough to justify the $67 \%$ increase in DTPA consumption. Considerable neodymium trailing occurred at $\mathrm{pH} 10$, indicating formation of small amounts of neodymium hydroxide in the column.

These lab-scale results were confirmed in semiworks tests. At the end of the chromatographic separation tests, residual lanthanides were completely removed from the resin with 2 column volumes of $0.3 \mathrm{M}$ DTPA at $\mathrm{pH} 8.0$. 


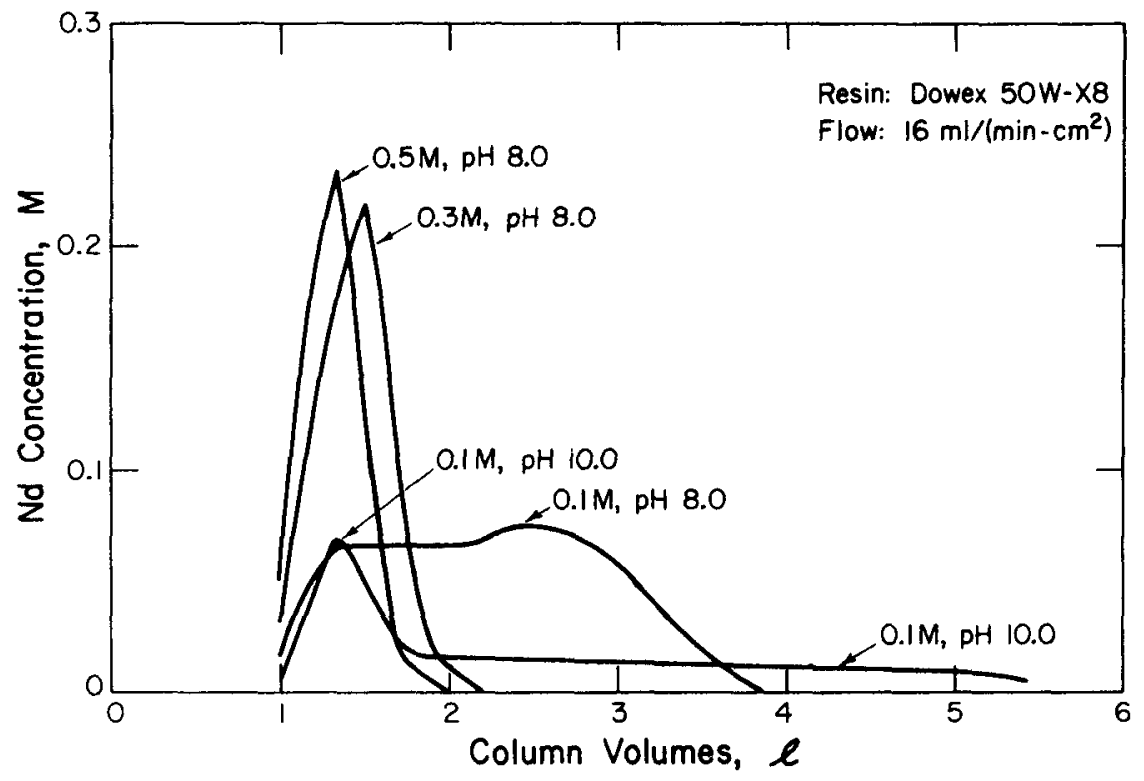

FIGURE 7. Removal of Neodymium from a 1/3-Loaded Column with DTPA 


\section{PROPOSED PROCESS}

The ion exchange process for plutonium burner concentrate comprises three parts: 1) loading step, 2) separation of americium and curium by displacement development chromatography with $0.05 \mathrm{M}$ DTPA at $\mathrm{pH} 3.0$ as elutriant, and 3) residual fission product stripping with $0.3 \mathrm{M}$ DTPA at $\mathrm{pH} 8.0$.

The ion exchange columns to be used are $8,6,4$, and 2 inches in diameter. All columns are $4 \mathrm{ft}$ long except the 8-inch column, which is $5 \mathrm{ft}$ long. With this process, 18 moles of $\mathrm{In}+\mathrm{An}$ can be separated from solution containing $1 \mathrm{M} \mathrm{HNO}_{3}$ and $2 \mathrm{M}$ $\mathrm{NaNO}_{3}$. Largex concentrations of $\mathrm{NaNO}_{3}$ and $\mathrm{HNO}_{3}$ decrease the batch size by decreasing colum capacity for LntAn. The maximum LntAn batch size for any $\mathrm{HNO}_{3}$ and $\mathrm{NaNO}_{3}$ concentration can be determined from Figure 1.

Curium and americium can be separated from each other and from fission products with $0.05 \mathrm{M}$ DTPA at $\mathrm{pH} 3.0$ as elutriant. A $\mathrm{Cm}-\mathrm{Am}$ binary containing $230 \mathrm{~g}$ of each component can be obtained with a flow of $16 \mathrm{ml} /\left(\mathrm{min}-\mathrm{cm}^{2}\right)$ through the 8-, 6-, and 4-inch columns and $32 \mathrm{ml} /\left(\mathrm{min}-\mathrm{cm}^{2}\right)$ through the $2-i n c h$ column. At these flows and a water jacket temperature of $70^{\circ} \mathrm{C}$, $\sim 1000$ watts can be processed through the 2-inch column without overheating the resin bed. After curium and americium are collected, residual fission products can be stripped from the resin with $\sim 2$ column volumes of $0.3 \mathrm{M}$ DTPA at $\mathrm{pH} 8.0$. 


\section{ACKNOWLEDGMENT}

R. M. Wallace and R. L. Snow assisted in developing the equilibrium model for cation exchange sorption (Appendix A). The computer code for calculating band length requirements (Appendix B) was written by J. T. Lowe. 


\section{APPENDIX A \\ EQUILIBRIUM TREATMENT FOR COLUMN LOADING ${ }^{2}$}

An equilibrium model describing the sorption by cation exchange resin of an $n$-valent and two monovalent cations from solution is characterized by the following equations:

$$
\begin{gathered}
\mathrm{M}^{\mathrm{n}+}+\mathrm{n} \overline{\mathrm{M}}_{2}^{+}=\overline{\mathrm{M}}^{\mathrm{n}+}+\mathrm{nM}_{1}^{+} \\
\mathrm{M}^{\mathrm{n}+}+\mathrm{n}_{\mathrm{M}_{2}^{+}}^{+}=\overline{\mathrm{M}}^{\mathrm{n}+}+\mathrm{nM}_{2}^{+} \\
\mathrm{K}_{1}=\frac{\left(\overline{\mathrm{M}}^{\mathrm{n}+}\right)\left(\mathrm{M}_{2}^{+}\right)^{\mathrm{n}}}{\left(\mathrm{M}^{\mathrm{n}+}\right)\left(\overline{\mathrm{M}}_{1}^{+}\right)^{\mathrm{n}}} \\
{ }^{+}
\end{gathered}
$$

Parentheses denote phases, and the bis. . . he aqueous and resin

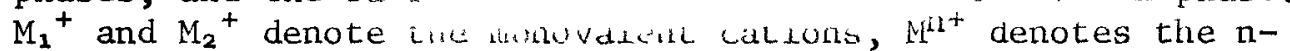
valent cations, and $K_{1}$ and $K_{2}$ are equilibrium constants for Equations 1 and 2. During column operations, the equilibrium concentration of the "ion initially sorbed on the resin is negligible, and, thereso, it is not necessary to consider it in the equilibrium model.

The capacity of the resin is defined by Equation 5 .

$$
\mathrm{C}=\mathrm{n}\left[\overline{\mathrm{M}}^{\mathrm{n}+}\right]+\left[\overline{\mathrm{M}}_{1}^{+}\right]+\left[\overline{\mathrm{M}}_{2}^{+}\right]
$$

where $C$ is the resin capacity in meq/g. Square brackets denote concentrations in meq/g in the resin phase and molarity in the aqueous phase. 
Combining Equations 3 through 5 gives

$$
\begin{gathered}
\left(\overline{\mathrm{M}}_{1}^{+}\right)=\left[\overline{\mathrm{M}}_{1}^{+}\right] \bar{\gamma}_{\mathrm{M}_{1}}+=\left(\frac{\left(\overline{\mathrm{M}}^{\mathrm{n}+}\right)}{\mathrm{K}_{1}\left(\mathrm{M}^{\mathrm{n}+}\right)}\right)^{1 / \mathrm{n}}\left(\mathrm{M}_{1}^{+}\right) \\
\left(\overline{\mathrm{M}}_{2}^{+}\right)=\left[\overline{\mathrm{M}}_{2}^{+}\right] \bar{\gamma}_{\mathrm{M}_{2}}+=\left(\frac{\left(\overline{\mathrm{M}}^{\mathrm{n}}\right)}{\mathrm{K}_{2}\left(\mathrm{M}^{\mathrm{n}+}\right)}\right)^{1 / \mathrm{n}}\left(\mathrm{M}_{2}^{+}\right) \\
\mathrm{C}=\mathrm{n}\left[\overline{\mathrm{M}}^{\mathrm{n}+}\right]+\frac{\left[\overline{\mathrm{M}}^{\mathrm{n}+}\right]^{1 / \mathrm{n}}\left(\bar{\gamma}_{\mathrm{M}^{\mathrm{n}}}{ }^{+}\right)}{\left(\mathrm{M}^{\mathrm{n}+}\right)^{1 / \mathrm{n}}}\left(\frac{\left(\mathrm{M}_{1}^{+}\right)}{\bar{\gamma}_{\mathrm{M}_{1}^{+}} \mathrm{K}_{1}^{1 / \mathrm{n}}}+\frac{\left(\mathrm{M}_{2}^{+}\right)}{\bar{\gamma}_{\mathrm{M}_{2}^{+}} \mathrm{K}_{2}^{1 / \mathrm{n}}}\right)
\end{gathered}
$$

where $\bar{\gamma}_{1}$ is the activity coefficient of species $i$ in the resin phase. The fraction of the resin, $f$, in the $\mathrm{M}^{\mathrm{n}^{+}}$form is given by Equation 9 .

$$
\mathrm{f}=\frac{\mathrm{n}\left[\overline{\mathrm{M}}^{\mathrm{n}+}\right]}{\mathrm{C}}
$$

Substitution of Equation 9 into Equation 8 gives Equation 10 .

$$
1=f+\sigma f^{1 / n}
$$

where

$$
\sigma=\left(\frac{\bar{\gamma}_{M^{n+}}}{n\left(M^{n+}\right) c^{n-1}}\right)^{1 / n}\left(\frac{{\left(M_{1}^{+}\right)}_{\bar{\gamma}_{M_{1}^{+}} K_{1}^{1 / n}}^{1 / n}}{\bar{\gamma}_{M_{2}^{+}} K_{2}^{1 / n}}\right)
$$

Equation 10 can be solved easily for $n=1,2,3$, and 4 . For sorption of a trivalent ion $(n=3)$ from a solution containing two monovalent cations, the solution is

$$
f=1-\sigma\left[\left[\frac{1}{2}+\left(\frac{1}{4}+\sigma^{3} / 27\right)^{\frac{1}{2}}\right]^{1 / 3}+\left[\frac{1}{2}-\left(\frac{1}{4}+\sigma^{3} / 27\right)^{\frac{1}{2}}\right]\right]^{1 / 3}
$$


Figure 1 shows a plot of $f$ versus $\sigma$, where $\sigma$ was calculated from Equation 11 assuning that ratios of the activity coeffictents in both phases (resin and aqueous) are constants, i.e.

$$
\sigma=a_{1}\left(\frac{\left[\mathrm{Na}^{+}\right]}{\left[\mathrm{Pr}^{9+}\right]^{1 / 3}}\right)+a_{2}\left(\frac{\left[\mathrm{H}^{+}\right]}{\left[\mathrm{Pr}^{3+}\right]^{3 / 9}}\right)
$$

where

$$
\begin{aligned}
& a_{1}=\left(\frac{1}{3 \mathrm{~K}_{1} \mathrm{C}^{2}}\right)\left(\frac{\left(\bar{\gamma}_{\mathrm{Pr}}^{3+}\right)^{2 / 3}}{\hat{\gamma}_{\mathrm{N} a^{+}}}\right)\left(\frac{\gamma_{\mathrm{Na}^{+}}}{\left(\gamma_{\mathrm{Pr}^{\mathrm{a}+}}\right)^{1 / 3}}\right) \\
& \mathrm{as}_{=}=\left(\frac{1}{3 \mathrm{~K}_{2} \mathrm{c}^{2}}\right)\left(\frac{\left(\bar{\gamma}_{\mathrm{Pr}^{3+}}\right)^{1 / 3}}{\bar{\gamma}_{\mathrm{H}^{+}}}\right)\left(\frac{\gamma_{\mathrm{H}^{+}}}{\left(\gamma_{\mathrm{Pr}^{3+}}\right)^{1 / 9}}\right)
\end{aligned}
$$

The values for $a_{2}$ and $a_{2}, 0.125$ and 0.057 , respectively, were obtained by a lesst squares analysis of the data dn Table III.

A slightly better fit of experimental data to the theoretical curve was obtained using calculated activity coefficieots. The method of Reflly, et at, was used to calculate activity coefficients in the aqueous phase. ${ }^{*}$ The paratseters $b_{2}$ and $b_{2}$ for this f1t are 0.145 and 0.024 , respectively, where

$$
\begin{aligned}
& b_{1}=\left(\frac{1}{3 \mathrm{~K}_{1} \mathrm{c}^{2}}\right)\left(\frac{\left(\overline{\mathrm{Y}}_{\mathrm{PI}^{3+}}\right)^{1 / 3}}{\tilde{\gamma}_{\mathrm{Na}^{+}}}\right) \\
& \mathrm{b}_{2}=\left(\frac{1}{3 k_{2} \mathrm{C}^{2}}\right)\left(\frac{\left(\bar{\gamma}_{\mathrm{Pr}^{3+}}\right)^{1 / 3}}{\bar{\gamma}_{\mathrm{H}^{+}}}\right)
\end{aligned}
$$

The ratio $\gamma_{\mathrm{Na}^{+}} /\left(\gamma_{\mathrm{Fr}^{3+}}\right)^{1 / 3}$ is atmost constant; the average value was $0.89 \pm 0.03$. The ratio $\gamma_{1+} /\left(\gamma_{\left.P_{2}+\right)^{2}} / 3\right.$, with an average value of $1.80 \pm 0.22$ (and $0.89 \mathrm{~b}_{1} \simeq \mathrm{a}_{1}$ and $1.80 \mathrm{~b}_{2} \simeq \mathrm{a}_{2}$ ), helps 
to explain the small difference in the fits of the experimental data in Figures 1 and 2 , and makes the initial assumptions regarding the activity coefficients more credible.

Since calculated activity coefficients for the aqueous phase only slightly improve the fit of experimental data to the theoretical curve, and the ratios of activity coefficients in the aqueous phase are almost constant, the more simple treatment using molar concentrations is preferred. 


\section{APPENDIX B}

\section{BAND LENGTH REQUIREMENTS FOR CURIUM-AMERICIUM SEPARATION}

A mathematical treatment by Helfferich and James ${ }^{5}$ describes the method for calculating band length requirements for steadystate resolution of a multicomponent mixture by displacement development chromatography. The method uses the roots of the "h-function" to calculate resolution distances and times. The $\mathrm{h}$-function is defined for an uncomplexed mixture by

$$
\sum_{i=1}^{n} \frac{y_{i}}{\frac{1}{h}-\frac{1}{\alpha_{1 i}}}=0
$$

where

$$
\begin{aligned}
n & =\text { the number of components } \\
y_{i} & =\text { the mole fraction of each component } \\
\alpha_{1 i} & =\text { the separation factor for component } 1 \text { and component } i
\end{aligned}
$$

The components are numbered so that the last element eluting from the column is component 1 .

The roots of the $\mathrm{h}$-function are bound by the separation factors. There are $n-1$ roots, then, satisfying the relations

$$
\alpha_{11} \leq h_{1} \leq \alpha_{12} \ldots \ldots \leq \alpha_{1,}{ }_{n-1} \leq h_{n-1} \leq \alpha_{1 n}
$$

The roots are determined by assuming a trial value for $h$ and calculating the sum in Equation 1. When values of $h$ are determined, equations in Table I of Reference 5 are used to calculate $\mathrm{T}_{j, k}$ and $\mathrm{Z}_{\mathrm{j}, \mathrm{k}}$ for all pairs of components, where $\mathrm{T}_{j, k}$ is the time in terms of initial band lengths required for components $j$ and $k$ to be resolved, and $Z_{j, k}$ is the distance the $j, k$ boundary has moved when the components are resolved. 
Table B-l shows a computer code written to perform these calculations. Input data for the computer program are given in Table B-2 for the plutonium burner concentrate. Tables B-3, B-4, and $\mathrm{B}-5$ show output from the computer program for the concentrate. 
TABLE B-1

Computer Code for Calculating Band Length Requirements

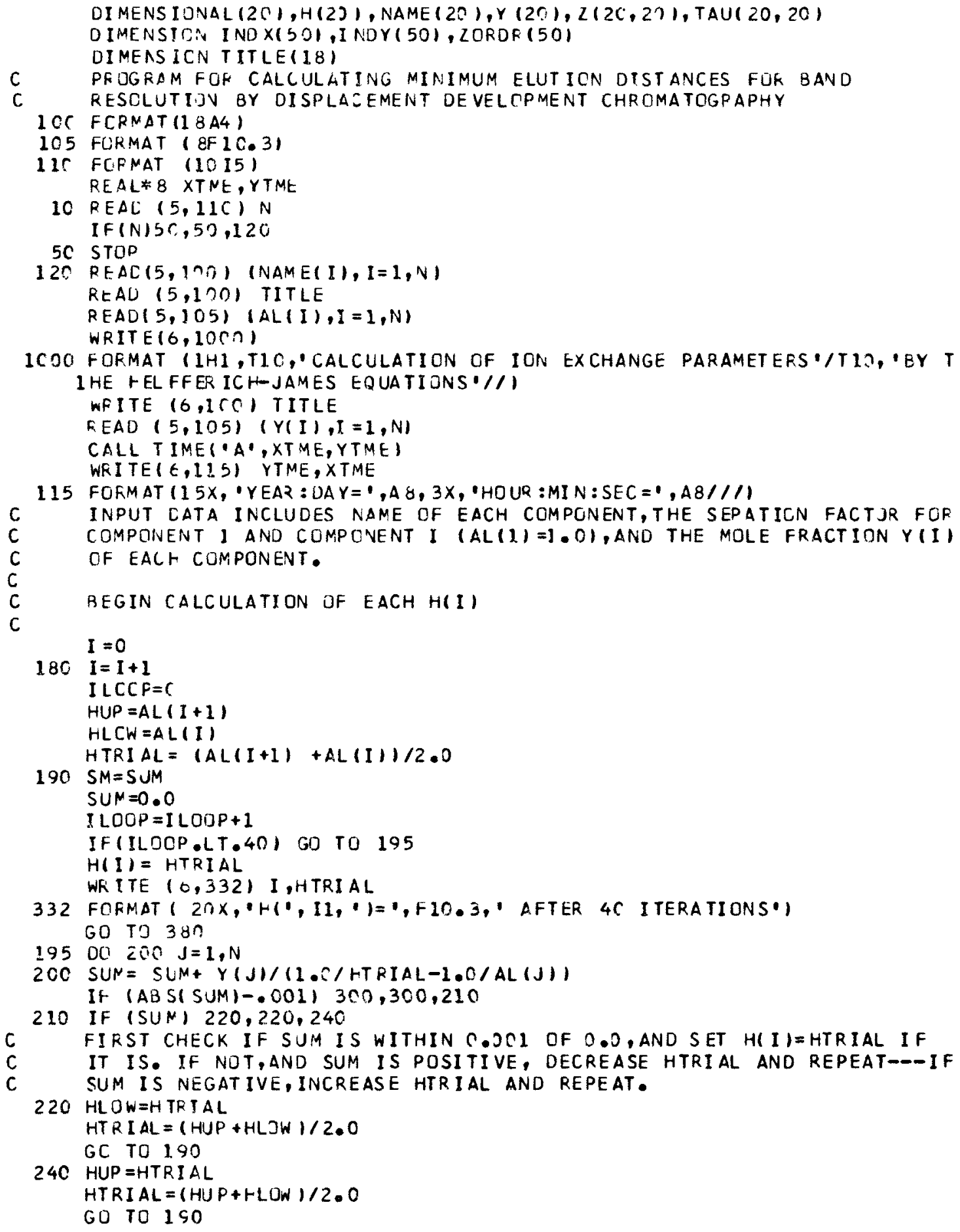




\section{TABLE B-1 (Cont'd)}

Computer Code for Calculating Band Length Requirements

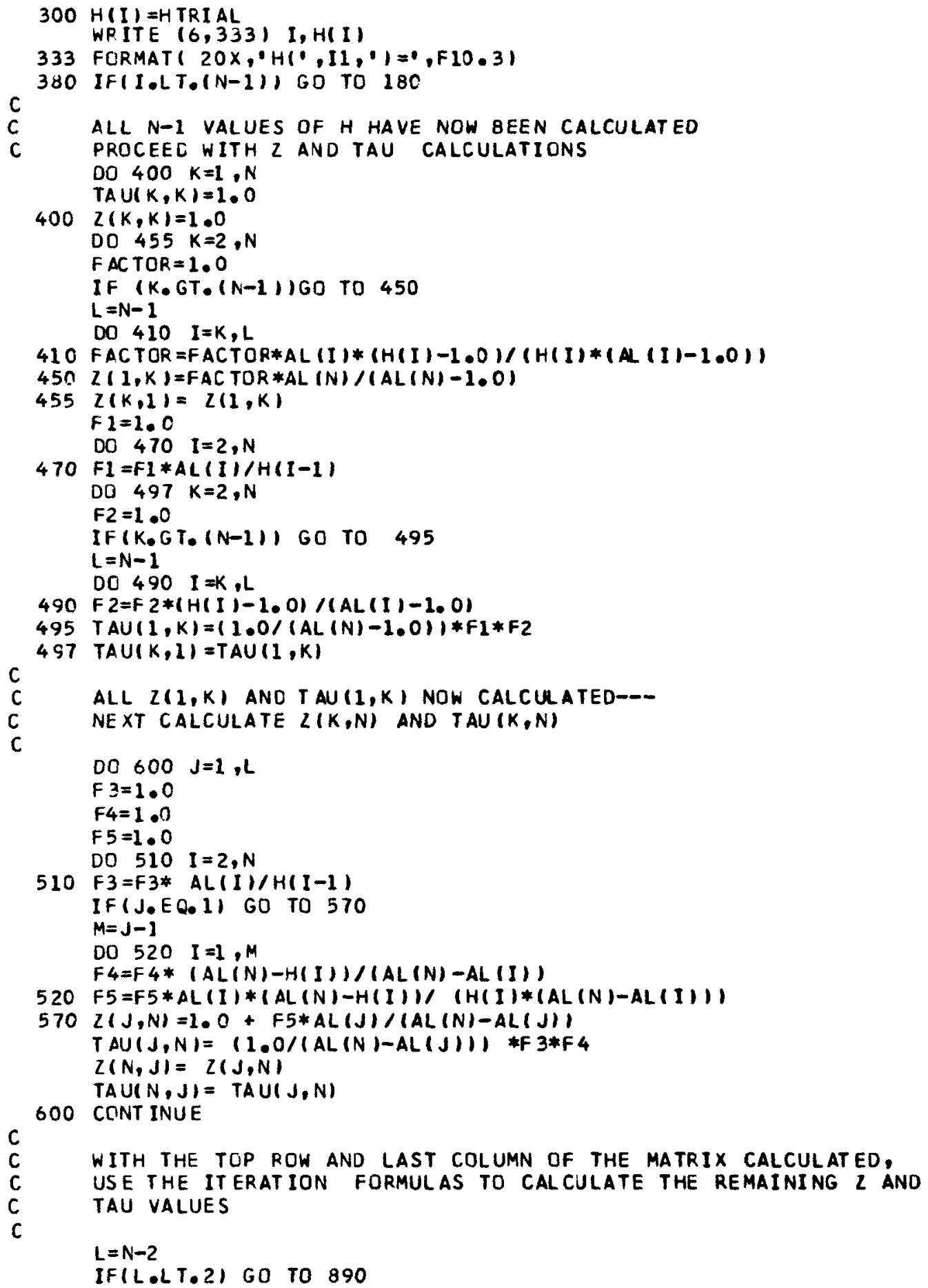


TABLE B-1 (Cont'd)

Computer Code for Calculating Band Length Requirements

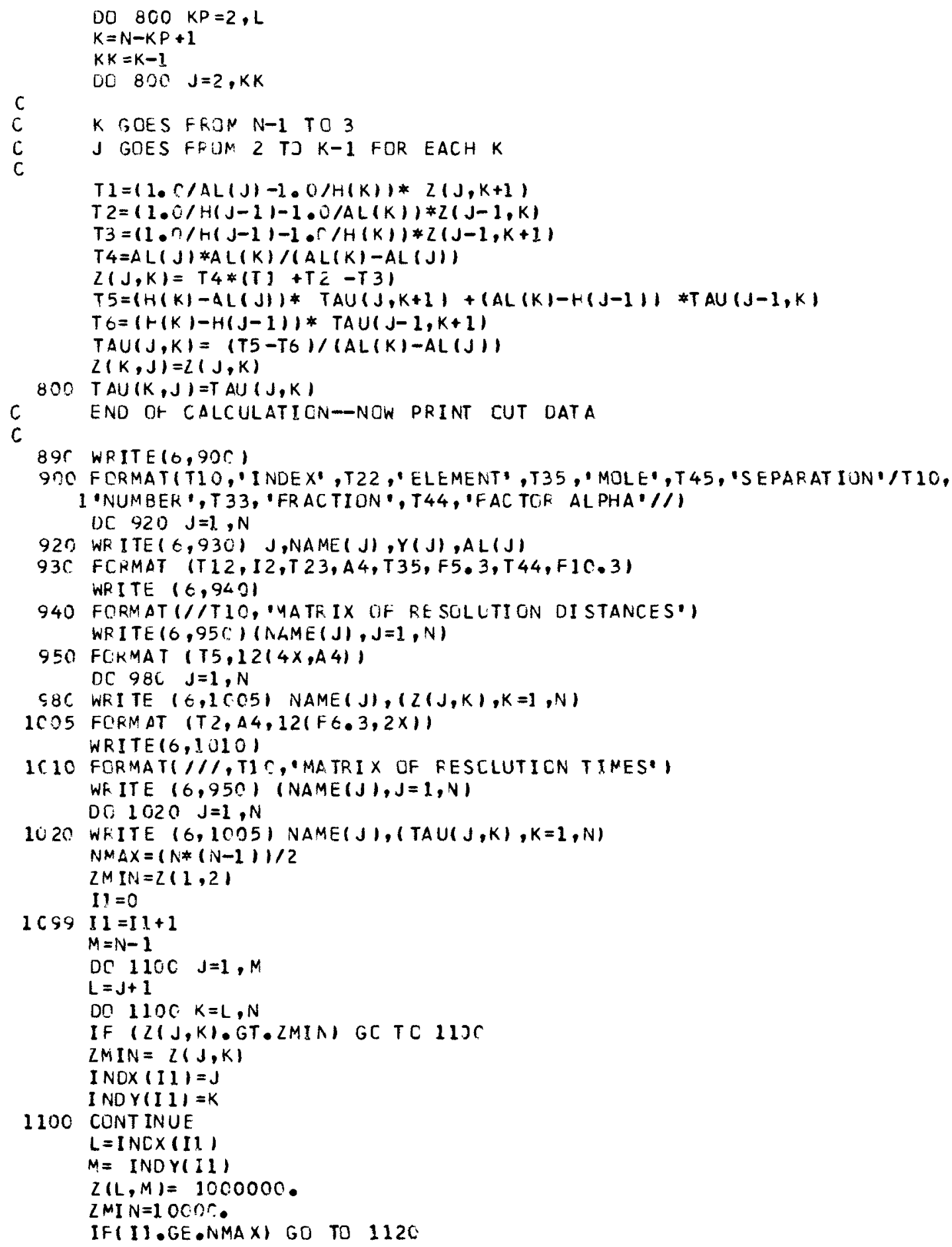




\section{TABLE B-1 (Cont'd)}

Computer Code for Calculating Band Length Requirements

GO TO 1099

1120 DO $113 \mathrm{C} J=1, \mathrm{~N}$

$L=J+1$

DC $1130 \mathrm{~K}=\mathrm{L}, \mathrm{N}$

$113 \mathrm{C} Z(J, K)=Z(K, J)$ WR ITE $(0,1140)$

1140 FORMAT $/ / / /, 10 \mathrm{X}$, 'COMPONENTS ARE RESOLVED IN THE FOLLOWING ORDER', $120 X_{1}$ 'COMP.] COMP. 2 DISTANCE TIME')

1150 FORM AT $(10 X, A 4,3 X, A 4,3 X, F 10,3,2 X, F 10,3)$

OC 1200 Il $=1$, NMAX

$L=I N D \times(11)$

$N=I \wedge D Y(I 1)$

$120 \mathrm{C}$ WFITE $(6,1150)$ NAME(L), NAME $(M), Z(L, M), T A U(L, M)$

GO TO 10

END 
TABLE B-2

Computer Code Input:

Composition of Mixture and Separation Factors

\begin{tabular}{|c|c|c|c|}
\hline $\begin{array}{l}\text { I ndex } \\
\text { Number } \\
\end{array}$ & Element & $\begin{array}{c}\text { Mole } \\
\text { Fraction } \\
\end{array}$ & $\begin{array}{l}\text { Separation } \\
\text { Factor, Alpha }\end{array}$ \\
\hline 1 & $\mathrm{La}$ & 0.114 & 1.000 \\
\hline 2 & $\mathrm{Ce}$ & 0.250 & 7.410 \\
\hline 3 & $\operatorname{Pr}$ & 0.108 & 29.520 \\
\hline 4 & $\mathrm{Nd}$ & 0.323 & 87.100 \\
\hline 5 & $\mathrm{Pm}$ & 0.005 & 186.200 \\
\hline 6 & $\mathrm{Sm}$ & 0.093 & 398.000 \\
\hline 7 & $\mathrm{Gd}$ & 0.016 & 589.000 \\
\hline 8 & $\mathrm{Eu}$ & 0.032 & 602.500 \\
\hline 9 & $\mathrm{Am}$ & 0.041 & 1202.000 \\
\hline 10 & $\mathrm{Cm}$ & 0.018 & 1380.000 \\
\hline
\end{tabular}


TABLE B-3

Computer Code Output:

Matrix of Resolution Times, $T_{j, k}$

$\begin{array}{lllllllllll} & \text { LA } & \text { CE } & \text { PR } & \text { ND } & \text { PM } & \text { SM } & \text { GD } & \text { EU } & \text { AM } & \text { CM } \\ \text { LA } & 1.000 & 0.940 & 0.672 & 0.577 & 0.290 & 0.267 & 0.209 & 0.208 & 0.140 & 0.126 \\ \text { CE } & 0.940 & 1.000 & 0.737 & 0.608 & 0.295 & 0.271 & 0.211 & 0.210 & 0.140 & 0.127 \\ \text { PR } & 0.672 & 0.737 & 1.000 & 0.751 & 0.309 & 0.281 & 0.217 & 0.215 & 0.143 & 0.129 \\ \text { ND } & 0.577 & 0.608 & 0.751 & 1.000 & 0.365 & 0.317 & 0.235 & 0.233 & 0.149 & 0.134 \\ \text { PM } & 0.290 & 0.295 & 0.309 & 0.365 & 1.000 & 0.332 & 0.242 & 0.239 & 0.151 & 0.135 \\ \text { SM } & 0.267 & 0.271 & 0.281 & 0.317 & 0.332 & 1.000 & 0.418 & 0.410 & 0.186 & 0.163 \\ \text { GD } & 0.209 & 0.211 & 0.217 & 0.235 & 0.242 & 0.418 & 1.000 & 2.288 & 0.210 & 0.179 \\ \text { EU } & 0.208 & 0.210 & 0.215 & 0.233 & 0.239 & 0.410 & 2.288 & 1.000 & 0.213 & 0.181 \\ \text { AM } & 0.140 & 0.140 & 0.143 & 0.149 & 0.151 & 0.186 & 0.210 & 0.213 & 1.000 & 0.493 \\ \text { CM } & 0.126 & 0.127 & 0.129 & 0.134 & 0.135 & 0.163 & 0.179 & 0.181 & 0.493 & 1.000\end{array}$

TABLE B-4

Computer Code Output:

Matrix of Resolution Distances, $z_{j, k}$

LA CE $P R$ ND $P M \quad S M \quad G D$ EU AM CM

$\begin{array}{llllllllllll}\text { LA } & 1.000 & 1.053 & 1.013 & 1.008 & 1.002 & 1.002 & 1.001 & 1.001 & 1.001 & 1.001 \\ \text { CE } & 1.053 & 1.000 & 1.101 & 1.057 & 1.016 & 1.013 & 1.009 & 1.009 & 1.005 & 1.005 \\ \text { PR } & 1.013 & 1.101 & 1.000 & 1.223 & 1.050 & 1.039 & 1.028 & 1.027 & 1.016 & 1.014 \\ \text { ND } & 1.008 & 1.057 & 1.223 & 1.000 & 1.160 & 1.115 & 1.077 & 1.076 & 1.043 & 1.038 \\ \text { PM } & 1.002 & 1.016 & 1.050 & 1.160 & 1.000 & 1.131 & 1.086 & 1.085 & 1.047 & 1.042 \\ \text { SM } & 1.002 & 1.013 & 1.039 & 1.115 & 1.131 & 1.000 & 1.310 & 1.303 & 1.114 & 1.099 \\ \text { GD } & 1.001 & 1.009 & 1.028 & 1.077 & 1.086 & 1.310 & 1.000 & 3.192 & 1.149 & 1.127 \\ \text { EU } & 1.001 & 1.009 & 1.027 & 1.076 & 1.085 & 1.303 & 3.192 & 1.000 & 1.154 & 1.130 \\ \text { AM } & 1.001 & 1.005 & 1.016 & 1.043 & 1.047 & 1.114 & 1.149 & 1.154 & 1.000 & 1.475 \\ \text { CM } & 1.001 & 1.005 & 1.014 & 1.038 & 1.042 & 1.099 & 1.127 & 1.130 & 1.475 & 1.000\end{array}$


TABLE B-5

\section{Computer Code Output: \\ order of Resolution}

COMPONENTS ARE RESOLVED IN THE FOLLOWING ORDER

$\begin{array}{cccl}\text { COMP.1 } & \text { COMP.2 } & \text { DISTANCE } & \text { TIME } \\ \text { LA } & \text { CM } & 1.001 & 0.126 \\ \text { LA } & \text { AM } & 1.001 & 0.140 \\ \text { LA } & \text { EU } & 1.001 & 0.208 \\ \text { LA } & \text { GD } & 1.001 & 0.209 \\ \text { LA } & \text { SM } & 1.002 & 0.267 \\ \text { LA } & \text { PM } & 1.002 & 0.290 \\ \text { CE } & \text { CM } & 1.005 & 0.127 \\ \text { CE } & \text { AM } & 1.005 & 0.140 \\ \text { LA } & \text { ND } & 1.008 & 0.577 \\ \text { CE } & \text { EU } & 1.009 & 0.210 \\ \text { CE } & \text { GD } & 1.009 & 0.211 \\ \text { CE } & \text { SM } & 1.013 & 0.271 \\ \text { LA } & \text { PR } & 1.013 & 0.672 \\ \text { PR } & \text { CM } & 1.014 & 0.129 \\ \text { CE } & \text { PM } & 1.016 & 0.295 \\ \text { PR } & \text { AM } & 1.016 & 0.143 \\ \text { PR } & \text { EU } & 1.027 & 0.215 \\ \text { PR } & \text { GD } & 1.028 & 0.217 \\ \text { ND } & \text { CM } & 1.038 & 0.134 \\ \text { PR } & \text { SM } & 1.039 & 0.281 \\ \text { PM } & \text { CM } & 1.042 & 0.135 \\ \text { ND } & \text { AM } & 1.043 & 0.149 \\ \text { PM } & \text { AM } & 1.047 & 0.151 \\ \text { PR } & \text { PM } & 1.050 & 0.309 \\ \text { LA } & \text { CE } & 1.053 & 0.940 \\ \text { CE } & \text { ND } & 1.057 & 0.608 \\ \text { ND } & \text { EU } & 1.076 & 0.233 \\ \text { ND } & \text { GD } & 1.077 & 0.235 \\ \text { PM } & \text { EU } & 1.085 & 0.239 \\ \text { PM } & \text { GD } & 1.086 & 0.242 \\ \text { SM } & \text { CM } & 1.099 & 0.163 \\ \text { CE } & \text { PR } & 1.101 & 0.737 \\ \text { SM } & \text { AM } & 1.114 & 0.186 \\ \text { ND } & \text { SM } & 1.115 & 0.317 \\ \text { GD } & \text { CM } & 1.127 & 0.179 \\ \text { EU } & \text { CM } & 1.130 & 0.181 \\ \text { PM } & \text { SM } & 1.131 & 0.332 \\ \text { GD } & \text { AM } & 1.149 & 0.210 \\ \text { EU } & \text { AM } & 1.154 & 0.213 \\ \text { ND } & \text { PM } & 1.160 & 0.365 \\ \text { PR } & \text { ND } & 1.223 & 0.751 \\ \text { SM } & \text { EU } & 1.303 & 0.410 \\ \text { SM } & \text { GD } & 1.310 & 0.418 \\ \text { AM } & \text { CM } & 1.475 & 0.493 \\ \text { GD } & \text { EU } & 3.192 & 2.288 \\ & & & \\ & & & \end{array}$




\section{REFERENCES}

1. W. H. Hale and J. T. Lowe. "Rapid, Gram-Scale Separation of Curium from Americium and Lanthanides by Cation Exchange Chromatography." Inorg. Nucl. Chem. Lett. 5, 363 (1969).

2. J. T. Lowe, W. H. Hale, and D. F. Hallman. "Development of a Pressurized Cation-Exchange Chromatographic Process for Separation of Transplutonium Actinides." Ind. Eng. Chem. Process Des. Develop. 10, 131 (1971).

3. F. W. E. Strelow, R. Rethemeyer, and C. J. C. Bothma. "Ion Exchange Selectivity Scales for Cations in $\mathrm{HNO}_{3}$ and $\mathrm{H}_{2} \mathrm{SO}_{4}$ Media with a Sulfonated Polystyrene Resin." Anal. Chem. 37 (1), 106 (1965).

4. J. A. Kelley, R. M. Wallace, and R. L. Snow. "Sorption of Praseodymium by Cation Exchange Resin from Mixtures of Sodium Nitrate and Nitric Acid." Ion Exchonge and Membrones 1,47 (1972).

5. F. G. Helfferich and D. B. James. "Equilibrium Theory for Rare-Earth Separation by Displacement Development." $J$. Chromatogr. 46, 1 (1970).

6. E. J. Wheelwright and T. R. Meyers. "Parametric Evaluation of DTPA, EDTA, and HEDTA for Ion Exchange Purification of Promethium." USAEC Report BNWL-69, Battelle Northwest Laboratory, Richland, Wash. (1965).

7. J. T. Lowe. "Isolation of ${ }^{147} \mathrm{Pm}$ by Rapid Cation Exchange Chromatography." USAEC Report DP-1194, E. I. du Pont de Nemours \& Co., Savannah River Laboratory, Aiken, S. C. (1969).

8. P. J. Reilly, R. H. Wood, and R. A. Robinson. "Prediction of Osmotic and Activity Coefficients in Mixed-Electrolyte Solution." J. Phys. Chem. 75, 1305 (1971).

TML: sce 